\title{
PRODUCTION OF NEGATIVE PIONS OF MEDICAL INTEREST BY HIGH-ENERGY PROTONS*
}

\author{
D. Berley, L.N. Blumberg, D.C. Bonar, R. Falrchild, J.D. Fox, W-C Lam, D.M. Lazarus \\ Y.Y. Lee, C.I. Wang, Brookhaven Nat'1 Laboratory, Upton, L.I.,N.Y. \\ A.S. Kanofsky, Lehigh U., Bethlehem, Pa., W.T. Chu, Loma LInda U., Loma Linda,Calif. \\ M. Blecher, Virginia Poly. Inst. \& State U., Blacksburg, Va.
}

\section{Abstract}

Improvements in intensity and availability of extracted proton beams from high energy acceleraturs lead to the possibility of forming negative pion beams useful for treating deep-seated cancers. ${ }^{1}$ To optimize pion fluxes and design parameters for such beams, an experiment was performed at the Brookhaven Alternating Gradient synchrotron to measure yields of negative pions produced by protons of 6 to $17 \mathrm{GeV} / \mathrm{c}$ incident on targets of different thickness and material. Measurements were made at production angles between $D^{\circ}$ and $30^{\circ}$ for pion momenta from 150 to $350 \mathrm{MeV} / \mathrm{c}$. A dose rate of $24 \mathrm{rads} / \mathrm{min}$ in a $100 \mathrm{~cm}^{2}$ field is attainable at the Alternating Gradient Synchrotron of the Brookhaven National Laboratory.

\section{Introduction}

It has now become possible to treat deep-seated tumors with charged particle radiotherapy. Negative pions are particularly attractive for this application as the Bragg peak at the end of their range is enhanced by the disintegration of the nuclef into which the negative pions are captured. This results in a large ratio of dose at the end of the range (at the tumor) to that delivered to healthy tissue through which the particles pass in reaching the tumor. Interest in radiotherapy using negative pions has recently been stimulated by estimates of the $\pi^{-}$fluxes expected at the Los Alamos Meson Physics Facility (IAMPF) when it comes into operation and presently aveilable at the AGS.

The only published measurement of the production of negative pions with momentum below $500 \mathrm{MeV} / \mathrm{c}$ at a multi-GeV accelerator is that of Fitch, Meyer and Piroue ${ }^{a}$ who obtained .09 and $.05 \pi^{-}$per steradian per $\mathrm{GeV} / \mathrm{c}$ per circulating proton produced at $45^{\circ}$ and $90^{\circ}$ respectively, relative to the beam incident on the internal target at the AGS. More recently a measurement of $200 \mathrm{MeV} / \mathrm{C}^{-}$production has been made at the AGS at $18.8^{\circ}$ to the internal target ${ }^{3}$ which gave a production of $.1-.4 \pi^{-}$per steradian per $\mathrm{GeV} / \mathrm{c}$ per interacting proton.

No data exist regarding the enhancement of lowenergy pion production by nuclear cascade although the effect is expected, and the expectation is supported by a Monte Carlo calculation ${ }^{4}$.

The useful negative pion intensity that can be de1 ivered to a tumor with minimum damage to surrounding healthy tissue depends, of course, on the beam transport to the patient, as well as the pion production. However, the beam parameters can be calculated to an adequate level of precision whereas it is at present important to have a bettcr knowledge of the production cross section, $\frac{\partial^{3} N}{\partial p \partial \Omega}$, and the cascade enhancement.

We have measured the negative pion production by protons in the pion momentum range $150 \mathrm{MeV} / \mathrm{c}$ to 350 $\mathrm{MeV} / \mathrm{c}$ at three proton momenta, 6,12 and $17 \mathrm{GeV} / \mathrm{c}$. Data was obtained at four production angles from $0^{\circ}$ to $30^{\circ}$ for three target materials $\mathrm{Al}, \mathrm{Cu}$ and $\mathrm{W}$. The dependence of pion yield on target length was investigated.

\footnotetext{
* Work performed under the auspices of the U.S. Atomic Energy Commission.
}

\section{Experiment}

The measurements were carried out in the East Test Bcam at the ACS. The beam is at $4.7^{\circ}$ to the internal target and it transported $10^{5}$ to $10^{6}$ protons per AGS cycle to our production target. The protons in this beam were available over a momentum range of 5 to $17 \mathrm{GeV} / \mathrm{c}$ with a transmitted momentum band of $\pm 2 \%$. The experimental arrangement is shown in Fig. 1. The protons were incident on the production target after passing through the Cerenkov counter, filled with Freon 12, which identified positive pions in the beam, and the three beam counters $S_{1}, S_{2}, S_{3}$ which were smaller in transverse dimensions than the target and therefore defined the target area through the trigger requirement. cerenkov counter efficiency measurements indicated that less than one percent of the triggers were on positive pions in the beam. Secondary particles produced in the target were momentum analyzed by the $72 \mathrm{D} 18$ (72-in. by 18-in. by 12-in. gap) spectrometer magnet and four pairs of scintillation counter hodoscopes. The spectrometer magnetic fleld was mapped both in and out of the median plane. The floating wire technique was used as a momentum calibration determining the positions of the hodoscopes. The secondary particles were bent through $30^{\circ}$.

Each hodoscope pair consisted of an upstream array of three $1-i n$. by $3-i n$. scintillation counters $U_{1}, U_{2}, U_{3}$ and a downstream array of four $2-i n$. by $8-i n$. counters $D_{1}-D_{4}$ as shown in Fig. 2. Each combination of counters $U_{i} D_{j}$ gives an angular resolution of $1.8^{\circ}$ corresponding ${ }^{1}{ }^{j}$ a momentum resolution $\frac{\Delta p}{p}=.06$. The event trigger used in the experiment was

$$
\mathrm{S}_{\mathrm{I}} \cdot \mathrm{s}_{2} \cdot \mathrm{S}_{3} \cdot \overline{\mathrm{C}} \cdot \mathrm{U}_{\mathrm{i}} \cdot \mathrm{D}_{\mathrm{j}} \cdot \mathrm{D}_{\mathrm{t}}
$$

$$
\text { where } j=i \text { or } i+1
$$

This produced a momentum acceptance $\frac{\Delta p}{p}=12 \%$. The region between the target and the downstream hodoscopes was enclosed in a system of helium bags in order to reduce multiple Coulomb scattering. Negative secondary particles were identified by their time of flight for the 16 -ft trajectory between the beam counter $S_{3}$ and a 2-in. by 8-in. scintillation counter placed immedialely behind each downstream hodoscope $D_{t}$. Peaks in the time of flight spectra corresponding to electrons and negative pions were observed. In order to separate the peaks cleanly, the outputs of the beam timing counter $S_{3}$ (XP1020 photomultiplier tube) and the downstream timing counters $D_{t}$ (56AVP photomultiplier) were clipped and zero crossing discriminators were used. The 8-in. length of the scintillators in the downstream timing counters would introduce a $2 / 3$ nanosec difference in transit time between particles incident at the end near the photomultiplier and those incident at the far end. This was reduced by using the downstream hodoscope counters $D_{f}$ to determine which half of the timing counter the particle passed through and introducing a suitable delay ( .3 nanosec) between signals from the two halves before routing them to the time to amplitude converters (TAC). Simultaneous time of flight spectra were taken for the four hodoscopes and stored in a 1024 channel pulse height analyzer. A time of flight resolution of .6 nanosec was achieved. A $200 \mathrm{MeV} / \mathrm{c}$ spectrum for $10^{\circ}$ production by $6 \mathrm{GeV} / \mathrm{c}$ protons is shown in Fig. 3 .

\section{Data and Analysis}

Table I indicates the matrix of proton and pion momenta studied along with target information. The 
data is tabulated in Table II.

In a given time interval the number of negative pions $\mathrm{N}_{T}$ detected in a downstream timing counter $\mathrm{D}_{\mathrm{T}}$ is

$$
N_{\pi}=N_{p} Y \Delta \Omega \Delta p \exp (-L / \gamma \beta c \tau)
$$

where $\mathrm{N}$ is the number of protons incident un the target in the time interval as defined by the beam counters, $Y$ is the number of $\pi^{-}$produced in the target,

$\triangle \triangle \Delta P$ is the acceptance of the hodoscope timing counter combination and the exponential factor is the decay factor, L being the time of flight path length, cT the proper time decay length, $780.2 \mathrm{~cm}$, for charged pions, $y=\left(1-3^{3}\right)^{-\frac{1}{2}}$. The yield $Y$ is then determined from the measurements of the other parameters in Eq. (1). N , the number of beam protons was corrected for acci- $P$ dentals by recording $S_{1} S_{a}{ }^{\prime} S_{3} \bar{C}$ where the prime indicates $S_{2}$ was timed aut of cuincidence with the uther beam counters. The maximum accidental rate was $2 \%$ for the bear counters and the positive pion contamination was less than $1 \%$

The acceptance $\Delta . \Delta p$ was computed with a Monte Carlo program which integrates the force equation along particle tranjectories through the field of the spectrometer magnet. A complete tabulation of the field of the spectrometer magnet was generated from the map of the vertical component of magnetic field in the median plane by symmetry and the requirements that curl $B=0$ and div $B=0^{5}$. The large bending angle of $30^{\circ}$ introduces large vertical focusing effects producing an increase in $\Delta \Omega \Delta p$ of up to $100 \%$ over the geometrical acceptance.

The largest uncertainty is in the number of pions detected. Although rate effects were negligible the large ratio of electrons to negative pions made backsround subtraction under the pion time of flight peak difficult especially at $0^{\circ}$ and low secondary momenta where $e^{-} / \pi^{-}$ratios exceeding $100 / 1$ were measured. Desplte the good time resolution there were sufficient electrons in the wings of the time of flight distribution to cause considerable uncertainty in the determination of the pion component. This was complicated by those muons arising from decay in flights of pions somewhere along the trajectory. Monte Carlo calculations indicated a maximum of $7 \%$ of the pion peak might be muons which would be indistinguishable from pions. Generally this contamination is less than $5 \%$ but these muons appear in between the pion and electron peaks in the time of flight spectra and are impossible to distinguish. Accidentals in the time of flight spectra are generally less than $1 \%$. The background subtraction was independently carried out by three physicists and the errors assigned reflect the consistency of their estimates. In general this produced a larger uncertainty in the results than counting statistics.

\section{Discussion of Results}

The results of sur measurements are sumarized in Figs. $4-6$, where the dependences of T $^{-}$production on incident proton romentum, pion momentum and on target thickness are shown. The thick target effects are the allowing:

1) Nucleon-meson cascade production: The highenergy secondaries produced by each inceracting proton will interact with other nucleons in the target to produce tertiaries, etc.

2. Target as degrader: pions undergo appreciable etiergy loss in the target and the observed pions must Lherefore have been produced at higher momentum, and thus with higher probability.

3) Seli-absorption by the target, which removes low momtun pions from the heam, is an increasing function of target thickness.

4) Multiple-scattering which is also an increasing function of target thickness, tends to obscure the angular dependence of pion production.

Measurements were made to investigate the "thick target effects" for the production of $200 \mathrm{MeV} / \mathrm{c}$ pions. Figure 4 shows that at an incident proton momentum of $6 \mathrm{GeV} / \mathrm{c}, 6$-in, of $\mathrm{Cu}$ is the optimum target thickness. The same thickness is almost optimum for $17 \mathrm{GeV} / \mathrm{c}$ incident protons. The angular variation plot of Fig. 5 shows that for a thick target negative pion production is nearly isotopic over our range of measurement. However, the $e^{-} / \pi^{-}$ratio drops rapidly with increasing angle. Figure 6 shows that for 6-in. Cu target, pion yield increases with both pion momentum and incident proton momentum.

In order to extrapolate to higher AGS energies, smooth curves were drawn through data points for 6,12 , and $17 \mathrm{GeV} / \mathrm{c}$ incident proton momenta and then the yield was plotted as a function of proton momentum as shown in Fig. 7. It was then extrapolated linearly to $30 \mathrm{GeV} / \mathrm{c}$. Figure 8 shows the dose rate obtainable from the AGS under the present operating conditions ( $6 \times 10^{12}$ protons/ sec) as a function of pion nomentum computed for a hypthetical beam $10 \mathrm{~m}$ long of $25 \mathrm{msr}$ acceptance. It is evaluated from the expression ${ }^{4}$

$$
D=\frac{Y \cdot \Delta r \cdot \Delta p \cdot \exp (-L / 2) \cdot f_{S} \cdot E_{S}}{A t C}
$$

where

$$
\begin{aligned}
& D=\text { dose rate }(\mathrm{rad} / \mathrm{sec}) \\
& \mathrm{L}=\text { beam length }(10 \mathrm{~m}) \\
& \lambda=\text { decay length for pions = } \gamma B C T \\
& f_{s}=\text { fraction surviving interactions in degrader } \\
& \text { before coming to rest } \\
& E_{S}=\text { energy deposited at end of stopping range }
\end{aligned}
$$

The range spread, $\Delta R$, which is a function of pion momentum is just the longitudinal dimension $t$ of the tumor volume. If one parameterizes the range in a power law of $\mathrm{T}_{\pi}$, pion kinetic energy, as $\mathrm{R}=\mathrm{aT}_{\pi}^{\mathrm{n}}$, then

$$
\Delta \mathrm{p}=\frac{\left(\mathrm{T}_{\pi}+\mathrm{m}_{\pi}\right)}{\mathrm{p}} \frac{\mathrm{t}}{\mathrm{ant}_{\pi}^{\mathrm{n}-1}}
$$

where $m_{m}$ and $p$ are pion wass and momentum respectively.

The fraction of pions surviving interactions with degrader material is estimated with the expression

$$
E_{S}=\exp \left[-N \int_{0}^{T} \sigma d T /|d T / d x|\right]
$$

where

$$
\begin{aligned}
T= & \text { kinetic total incrgy of pion at entrance } \\
& \text { to degrader } \\
\sigma= & \text { total interaction cross-section } \\
N= & \text { number of atoms } / \mathrm{cm}^{3}
\end{aligned}
$$

We have assumed the degrader has the density of body tissues of $1 \mathrm{gm} / \mathrm{cm}^{3}$ with average properties equivalent to that of carbon. The resulting dose vs pion momentum relationship has a maximum at about $200 \mathrm{M} \in \mathrm{V} / \mathrm{C}$ 
with a rate of $24 \mathrm{rads} / \mathrm{mtn}$ in a field of $100 \mathrm{~cm}^{2}$. This dose rate is considered quite adequate for the clinicel use of negative p1-meson in radiotherapy.

Table III lists the proton fluxes and dose rate from various accelerators in this country. At this time, the Los Alamos Scientific Laboratory is committed to a clinical trial of negative pion tumor therapy. When their $800 \mathrm{MeV}$ proton linac operates at the design intensity of $6 \times 10^{15}$ protons per sec., the biomedical channel would have a dose rate of $35 \mathrm{rads} / \mathrm{min}$ in a $100 \mathrm{~cm}^{2}$ fiels. A comparable flux of $24 \mathrm{rads} / \mathrm{min}$ would be obtainable from the AGS of the Brookhaven National Laboratory with the proton intensity which is available now. The pion fluxes available at the zGS and Bevatron were computed on the basis of the pion yield data from this work and the maximum proton intensties as indicated. However, machine Improvement programs are underway in all these laboratories; it is quite likely in the future that pion radiotherapy can be done at several locations around the nation.

\section{Acknowledgment}

We wish to thank H.L. Atkins, V.P. Bond, E.P. Cronkite and F.E. Mills for their interest and encouragement, and $T . J$. Blair for his assistance during the experiment. We are in debt to $G$. Bennett, $G$. Levine and $W$. More for their support. The interest of $R$. $R$. Rau was important for initiating this messurement. The excellent service from the AGS control room stafe: J. W. Glenn, A. Watts, A. McGeary, G. Comish and J. Gabusi was essential for the success of this experiment. The cooperation of D. Nygren and J. Chriatenson of the Columbla/NYU/ CERN group was appreclated.

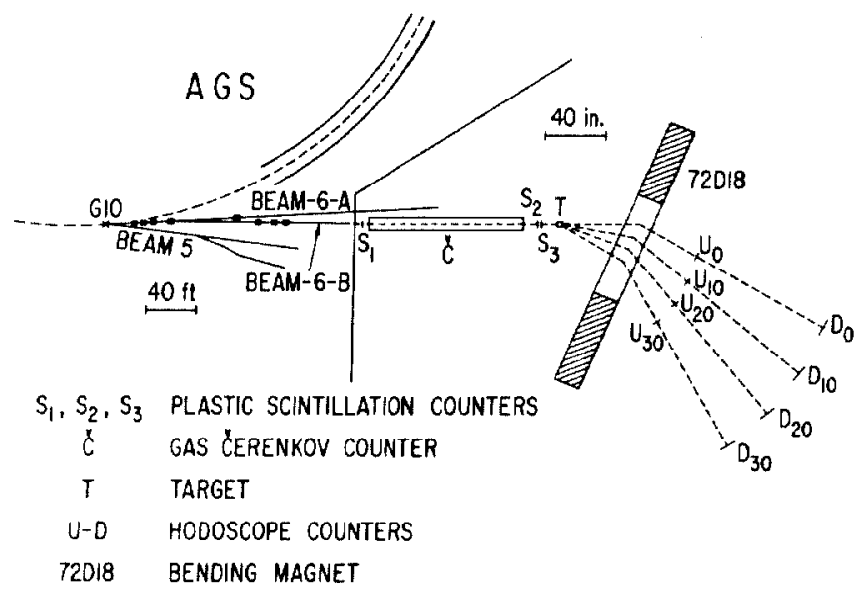

FIG.1 PIan view of experiment: Protons produced in the internal target at the AGS were transported in a beam chrough the proton telescope (plastic. scintillators $S_{1}, S_{3}, S_{3}$ and Cerenkov counter $C_{\text {) }}$ to the target $T$. Beam defining counter $S_{3}$ was $1.5^{\prime \prime}$ high by $1.25^{\prime \prime}$ wide. Target was $2^{\prime \prime} \times 2^{\prime \prime}$ in cross-section. Particles produced in $T$ were then analyzed by the $72 \mathrm{D} 18$ spectrometer magnet and the hodoscope system U-D.

\section{References}

1. V.P. Bond, Am.J. Roentgenology, Radium Therapy and Nuclear Medicine 111, 9 (1971).

2. V.L. Fitch, S.L. Meyer and P.A. Piroué, Phys. Rev. $126,1849,1962$.

3. D. Bassano, D.M. Lazarus and C.L. Wang, BNL Acce1erator Dept. Int. Rpt. EP\&S 71-6, 1972.

4. Proposal for the Use of the Brookhaven National Laboratory Alternating Gradient Synchrotron for Pi-minus Meson Therapy BNL 1971.

5. B. Zacharov, Nuc. Inst. and Meth. 33, 136, 1965.

6. R.I. Hutson and M. Jakobson, "The LAMPF Biomed Pion Channel: a Preliminary Report," MP-7-34 (1971).

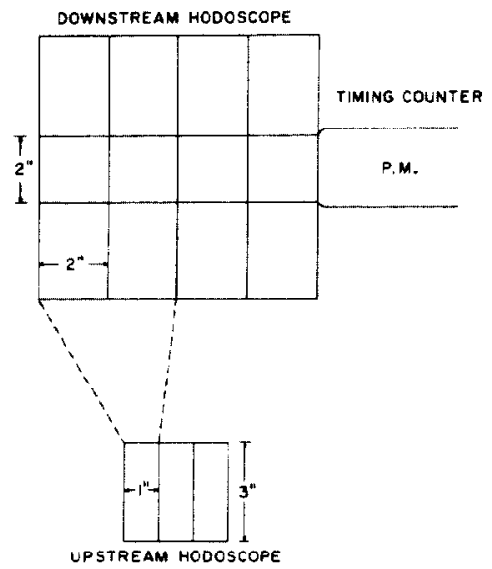

FIG.2 Conflguration of one of the four hodoscope scintillator arrays. Upstream array consisted of 3 counters $\mathrm{U}_{1}, \mathrm{U}_{2}, \mathrm{U}_{3}$. Downstream array consisted of 4 counters $D_{1}, D_{3}, D_{3}, D_{4}$ and a timing counter $D_{t .}$. Acceptance is determined by ${ }^{\circ} 3$ combinations of coincidence $U_{i} \cdot D_{j} \cdot D_{T}$ where $j=i$ or $1+1, i=1,2,3$.

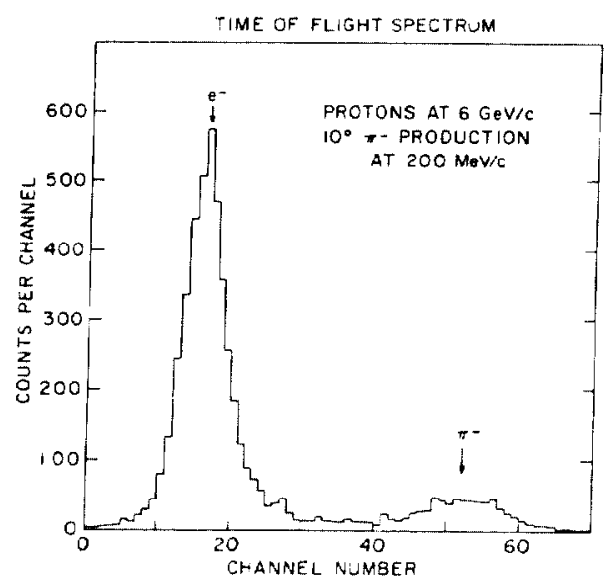

FIG.3 Time-of-flight spectrum for $200 \mathrm{MeV} / \mathrm{c}$ negative particles produced in a 3 "Cu target by $6 \mathrm{GeV} / \mathrm{c}$ protons. The time scale $1 \mathrm{~s} 10$ channels per ns. 


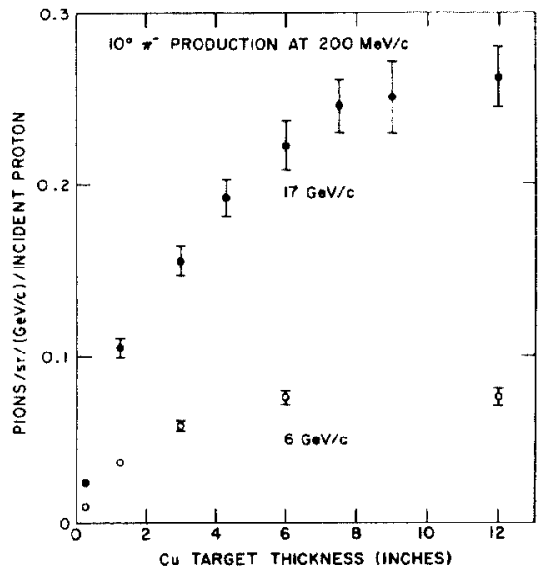

FIG.4. Negative pion production as a function of target thickness.

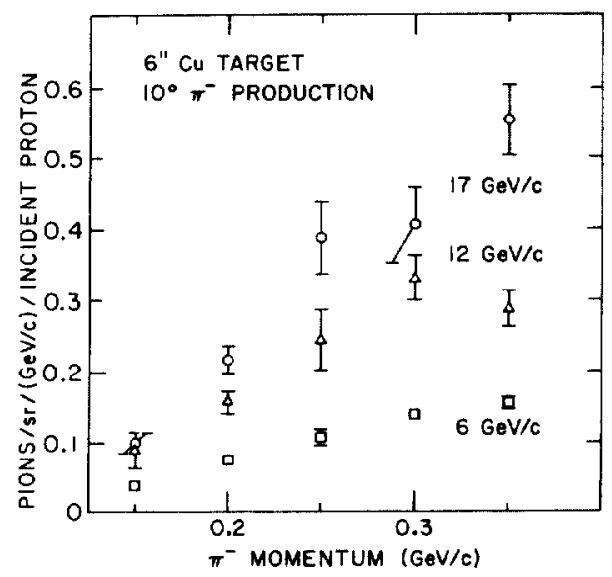

FIG.6 Negative pion momentum spectrum.

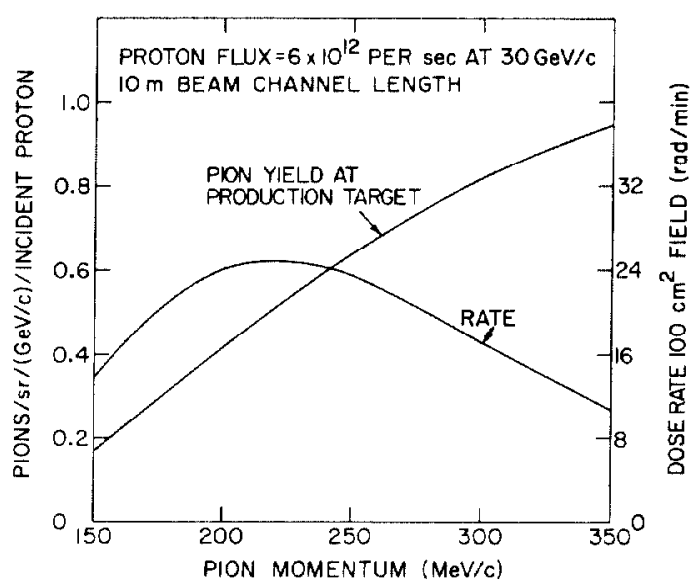

EIG.8 Negative pion flux and depth dose rate, estimated from data, and plotted as a function of pion momentum, for $100 \mathrm{~cm}^{2}$ field.

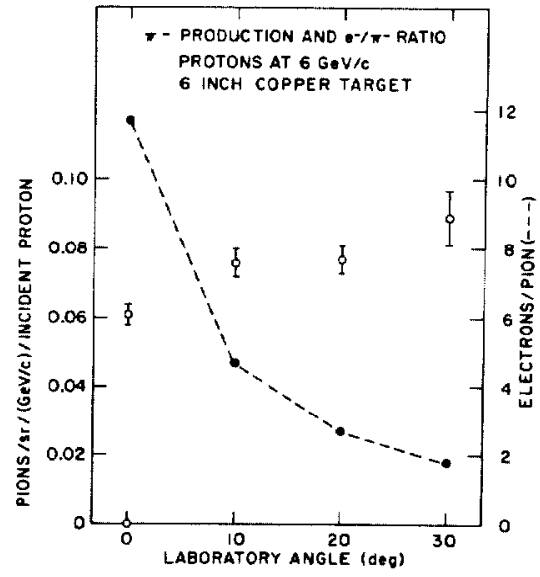

FIG. $5200 \mathrm{MeV} / \mathrm{c}$ negative pion production as a function of laboratory emission angle. The electron-pion ratio, measured at $16 \mathrm{ft}$ flight path, is also presented.

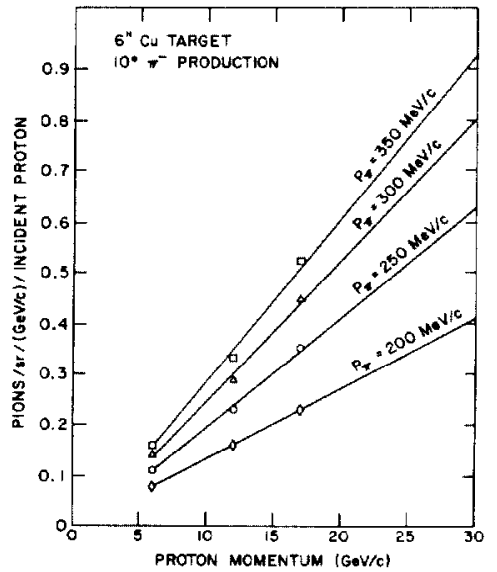

FIG.7 Negative pion production as a function of incident proton momentum derived from Fig. 6 . Error bars are not shown.

TABLE I

\begin{tabular}{|c|c|c|c|}
\hline \multirow{3}{*}{$\frac{\hat{a}}{\frac{a}{\alpha}} 150$} & \multicolumn{2}{|c|}{ Proton Momentum (GeV/c) } & \\
\hline & 6 & 12 & 17 \\
\hline & $\mathrm{Al}(\mathrm{I}), \mathrm{Cu}(\mathrm{I}), \mathrm{W}(\mathrm{I})$ & $\mathrm{Cu}(1)$ & $\operatorname{A1}(\mathrm{I}), \mathrm{Cu}(\mathrm{I}), W(\mathrm{I})$ \\
\hline 200 & $\operatorname{Al}(I), \operatorname{Cu}(\mathrm{L}), \mathrm{W}(\mathrm{I})$ & $\mathrm{Cu}(\mathrm{I}), \mathrm{Cu}(\mathrm{T})$ & $\operatorname{Al}(\mathrm{I}), \mathrm{Cu}(\mathrm{L}), \mathrm{L}(\mathrm{L})$ \\
\hline 250 & $A(I), C u(I), W(I)$ & $\mathrm{Cu}(\mathrm{I})$ & $\operatorname{Al}(I), \operatorname{Cu}(I), W(I)$ \\
\hline 300 & $\mathrm{~A} 1(\mathrm{I}), \mathrm{Cu}(\mathrm{I}), \mathrm{H}(\mathrm{I})$ & $\mathrm{Cu}(\mathrm{I})$ & $\mathrm{Al}(\mathrm{I}), \mathrm{Cu}(\mathrm{I}), W(\mathrm{I})$ \\
\hline 350 & $\mathrm{Al}(\mathrm{I}), \mathrm{Cu}(\mathrm{I}), \mathrm{W}(\mathrm{I})$ & $\operatorname{Cu}(\mathrm{I}), \operatorname{Cu}(\mathrm{T})$ & $\mathrm{Al}(\mathrm{I}), \mathrm{Cu}(\mathrm{I}), \mathrm{W}(\mathrm{I})$ \\
\hline
\end{tabular}

Stmary of negative pion yield measurements. The subscript in parenthes 1o denotes: I - one 1nteraction length; $L$ - as function of target thickness; $\mathrm{T}=0.25^{\prime \prime}$ target. 
TABLE II: SUMMARY OF RESULTS OF PION PRODUCTION MEASUREMENT

\begin{tabular}{|c|c|c|c|c|c|c|c|c|c|c|c|c|c|c|}
\hline $\begin{array}{l}P(P) \\
G E V / C\end{array}$ & $\begin{array}{l}P(P,) \\
M E V, C\end{array}$ & $\begin{array}{l}\text { PARGET } \\
\text { INGHES }\end{array}$ & $Y J E L D^{0}$ & $\begin{array}{l}\text { DEGREES } \\
\text { ERROR }\end{array}$ & $E, P I$ & YIELD & $\begin{array}{l}\text { DEBREES } \\
\text { ERROR }\end{array}$ & $E / P \mid$ & $Y$ YEL 20 & $\begin{array}{l}\text { DEOREES } \\
\text { ERROR }\end{array}$ & $E / P !$ & YIELD & $\begin{array}{l}\text { DEGREES } \\
\text { ERROK }\end{array}$ & $E / P I$ \\
\hline $\begin{array}{l}6 \\
6 \\
6 \\
6 \\
6\end{array}$ & $\begin{array}{l}200 \\
200 \\
200 \\
200 \\
200\end{array}$ & $\begin{array}{r}.25 \text { (cu) } \\
1,25 \text { (cu) } \\
3,07 \text { (eu) } \\
6,00 \text { icus } \\
12,30 \text { (eus) }\end{array}$ & $\begin{array}{l}.000 \\
.032 \\
0055 \\
.059 \\
.043\end{array}$ & $\begin{array}{l}.001 \\
.002 \\
005 \\
0005 \\
003\end{array}$ & $\begin{array}{r}39.09 \\
16,28 \\
19.42 \\
5,27 \\
4,33\end{array}$ & $\begin{array}{l}.010 \\
.036 \\
.058 \\
.078 \\
.077\end{array}$ & $\begin{array}{l}.001 \\
.002 \\
0003 \\
.004 \\
.005\end{array}$ & $\begin{array}{l}1,50 \\
4,75 \\
3,95 \\
2,10 \\
2,30\end{array}$ & $\begin{array}{l}.008 \\
.050 \\
.852 \\
.079 \\
.107\end{array}$ & $\begin{array}{l}.001 \\
.002 \\
.003 \\
.004 \\
.005\end{array}$ & $\begin{array}{l}.76 \\
2.35 \\
1.94 \\
1.11 \\
1.50\end{array}$ & $\begin{array}{l}.008 \\
: 031 \\
: 048 \\
: 089 \\
.127\end{array}$ & $\begin{array}{l}.001 \\
1003 \\
1004 \\
1008 \\
.006\end{array}$ & $\begin{array}{l}01 \\
1: 17 \\
1: 91 \\
197 \\
197\end{array}$ \\
\hline $\begin{array}{l}17 \\
17 \\
17 \\
17 \\
17 \\
17 \\
17 \\
17\end{array}$ & $\begin{array}{l}200 \\
200 \\
200 \\
200 \\
200 \\
200 \\
200 \\
200\end{array}$ & 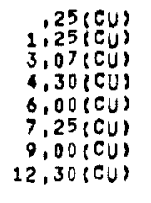 & $\begin{array}{l}.024 \\
.079 \\
0.243 \\
1107 \\
.201 \\
.207 \\
.220 \\
.145\end{array}$ & $\begin{array}{l}.003 \\
, 008 \\
0025 \\
0027 \\
0.018 \\
, 033 \\
, 021 \\
, 029\end{array}$ & $\begin{array}{l}11.39 \\
25: 11 \\
11: 49 \\
31.20 \\
18: 12 \\
24: 21 \\
19.48 \\
20.97\end{array}$ & $\begin{array}{l}.024 \\
: 1105 \\
: 158 \\
: 193 \\
.220 \\
.248 \\
.253 \\
.265\end{array}$ & $\begin{array}{l}.002 \\
.006 \\
.008 \\
.018 \\
020 \\
016 \\
.021 \\
.018\end{array}$ & $\begin{array}{l}2,16 \\
5: 16 \\
8,80 \\
8,68 \\
5,05 \\
5,44 \\
7,96 \\
5,85\end{array}$ & $\begin{array}{l}.021 \\
.065 \\
1139 \\
153 \\
1181 \\
.224 \\
.286 \\
.278\end{array}$ & $\begin{array}{l}.003 \\
.004 \\
000 \\
0010 \\
0010 \\
0.060 \\
.022 \\
.028\end{array}$ & $\begin{array}{l}1.01 \\
3.06 \\
3.24 \\
3.57 \\
2.20 \\
3.41 \\
3.31 \\
3.20\end{array}$ & $\begin{array}{l}.015 \\
: 051 \\
0109 \\
.147 \\
.195 \\
.206 \\
.346 \\
.343\end{array}$ & $\begin{array}{l}.002 \\
.004 \\
.012 \\
.015 \\
.017 \\
.027 \\
.017 \\
.038\end{array}$ & $\begin{array}{l}, 58 \\
1,61 \\
1,79 \\
1,57 \\
1,87 \\
1,27 \\
1,17 \\
1,42\end{array}$ \\
\hline $\begin{array}{l}17 \\
17 \\
17 \\
17 \\
17 \\
17\end{array}$ & $\begin{array}{l}200 \\
200 \\
200 \\
200 \\
200 \\
200\end{array}$ & 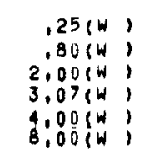 & $\begin{array}{l}.019 \\
.098 \\
: 177 \\
: 186 \\
.205 \\
: 157\end{array}$ & $\begin{array}{l}.003 \\
.009 \\
.028 \\
.020 \\
.023 \\
.018\end{array}$ & $\begin{array}{r}11.71 \\
24.53 \\
13.66 \\
7.05 \\
6.73 \\
4.47\end{array}$ & $\begin{array}{l}.020 \\
.110 \\
.200 \\
.165 \\
.256 \\
.223\end{array}$ & $\begin{array}{l}.003 \\
.009 \\
.024 \\
.012 \\
.024 \\
.021\end{array}$ & $\begin{array}{l}2,88 \\
5,14 \\
3,26 \\
2,10 \\
1,53 \\
, 93\end{array}$ & $\begin{array}{l}.018 \\
.085 \\
1148 \\
1162 \\
1269 \\
1217\end{array}$ & $\begin{array}{l}.007 \\
.011 \\
0012 \\
012 \\
010 \\
015 \\
015\end{array}$ & $\begin{array}{r}1.53 \\
2.27 \\
1.12 \\
.54 \\
.33 \\
.35\end{array}$ & $\begin{array}{l}.020 \\
.084 \\
.146 \\
.165 \\
.1285 \\
.240\end{array}$ & $\begin{array}{l}.003 \\
.010 \\
.020 \\
.020 \\
.025 \\
.026\end{array}$ & $\begin{array}{l}.99 \\
88 \\
55 \\
28 \\
28 \\
417\end{array}$ \\
\hline $\begin{array}{l}6 \\
6 \\
8 \\
8 \\
6\end{array}$ & $\begin{array}{l}150 \\
200 \\
250 \\
300 \\
350\end{array}$ & $\begin{array}{l}11,00(A L) \\
11,00(A L L) \\
11,00(A L) \\
11,00(C L) \\
11.00(A L)\end{array}$ & $\begin{array}{l}.030 \\
.085 \\
0.090 \\
.089 \\
.053\end{array}$ & $\begin{array}{l}.036 \\
.004 \\
0011 \\
.017 \\
.030\end{array}$ & $\begin{array}{l}55,70 \\
29.51 \\
23,30 \\
24,69 \\
31.90\end{array}$ & $\begin{array}{l}.048 \\
.075 \\
.011 \\
.139 \\
.152\end{array}$ & $\begin{array}{l}.005 \\
.007 \\
.001 \\
.018 \\
.026\end{array}$ & $\begin{array}{l}7,56 \\
3,84 \\
2,02 \\
1,50 \\
1,16\end{array}$ & $\begin{array}{l}.049 \\
.057 \\
.1215 \\
.233 \\
.212\end{array}$ & $\begin{array}{l}.005 \\
.004 \\
.025 \\
.015 \\
.013\end{array}$ & $\begin{array}{r}3.24 \\
2.00 \\
.89 \\
.35 \\
.37\end{array}$ & $\begin{array}{l}.055 \\
.077 \\
.137 \\
.153 \\
.143\end{array}$ & $\begin{array}{l}.004 \\
.008 \\
.016 \\
.007 \\
.007\end{array}$ & $\begin{array}{r}1.09 \\
.01 \\
29 \\
222 \\
119\end{array}$ \\
\hline $\begin{array}{l}6 \\
5 \\
8 \\
8 \\
5\end{array}$ & $\begin{array}{l}150 \\
200 \\
250 \\
300 \\
350\end{array}$ & $\begin{array}{l}0.00(E U) \\
6.00(E U) \\
6.00(E U) \\
0.00(E U) \\
0.00(E U)\end{array}$ & $\begin{array}{l}.628 \\
.099 \\
.201 \\
.108 \\
.139\end{array}$ & $\begin{array}{l}.005 \\
.005 \\
012 \\
010 \\
.011\end{array}$ & $\begin{array}{r}15.96 \\
5.27 \\
2.85 \\
2.13 \\
1.22\end{array}$ & $\begin{array}{l}.038 \\
.076 \\
.109 \\
.140 \\
.156\end{array}$ & $\begin{array}{l}.005 \\
0004 \\
0011 \\
006 \\
.008\end{array}$ & $\begin{array}{l}6,21 \\
2,16 \\
1,16 \\
, 65 \\
, 10\end{array}$ & $\begin{array}{l}.050 \\
.079 \\
1126 \\
1155 \\
.156\end{array}$ & $\begin{array}{l}.005 \\
.004 \\
.013 \\
.009 \\
.008\end{array}$ & $\begin{array}{r}2.23 \\
1.11 \\
.10 \\
.25 \\
.27\end{array}$ & $\begin{array}{l}.054 \\
.089 \\
.130 \\
.144 \\
.131\end{array}$ & $\begin{array}{l}.005 \\
.008 \\
.009 \\
.000 \\
.000\end{array}$ & $\begin{array}{r}1,74 \\
: 74 \\
: 24 \\
.22\end{array}$ \\
\hline $\begin{array}{l}6 \\
5 \\
6 \\
6 \\
6\end{array}$ & $\begin{array}{l}150 \\
200 \\
250 \\
300 \\
350\end{array}$ & 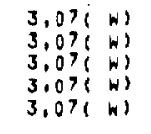 & $\begin{array}{l}.036 \\
.062 \\
0.08 \\
.112 \\
.117\end{array}$ & $\begin{array}{l}.004 \\
.004 \\
0005 \\
0006 \\
.010\end{array}$ & $\begin{array}{r}3.49 \\
1.64 \\
.90 \\
.61 \\
.49\end{array}$ & $\begin{array}{l}.037 \\
.067 \\
1103 \\
1106 \\
.122\end{array}$ & $\begin{array}{l}.003 \\
.005 \\
.006 \\
.006 \\
.007\end{array}$ & $\begin{array}{l}1,94 \\
1,06 \\
130 \\
125 \\
119\end{array}$ & $\begin{array}{l}.048 \\
.054 \\
.101 \\
1113 \\
1111\end{array}$ & $\begin{array}{l}.003 \\
.006 \\
.005 \\
.006 \\
.007\end{array}$ & $\begin{array}{l}.87 \\
.35 \\
.16 \\
.16 \\
.08\end{array}$ & $\begin{array}{l}.042 \\
.058 \\
.088 \\
.092 \\
.093\end{array}$ & $\begin{array}{l}.003 \\
.005 \\
.000 \\
.006 \\
.006\end{array}$ & $\begin{array}{l}47 \\
21 \\
08 \\
111 \\
.08\end{array}$ \\
\hline $\begin{array}{l}12 \\
12 \\
12 \\
12 \\
12\end{array}$ & $\begin{array}{l}150 \\
200 \\
250 \\
300 \\
350\end{array}$ & $\begin{array}{l}6.00(\mathrm{Cu}) \\
6,001 \mathrm{Cu} \\
6,001 \mathrm{Cu} \\
6,00104 \\
6.00104\end{array}$ & $\begin{array}{r}107 \\
1144 \\
229 \\
263 \\
2305\end{array}$ & $\begin{array}{l}.030 \\
.016 \\
032 \\
.026 \\
.034\end{array}$ & $\begin{array}{r}24,53 \\
11.20 \\
5,24 \\
4.23 \\
2,64\end{array}$ & $\begin{array}{r}.089 \\
: 158 \\
1247 \\
3336 \\
293\end{array}$ & $\begin{array}{l}.027 \\
.016 \\
: 045 \\
.034 \\
.026\end{array}$ & $\begin{array}{r}11,92 \\
3,57 \\
1,79 \\
1,02 \\
177\end{array}$ & $\begin{array}{l}.088 \\
1152 \\
1274 \\
1465 \\
1375\end{array}$ & $\begin{array}{l}.026 \\
.013 \\
.090 \\
.034 \\
.028\end{array}$ & $\begin{array}{r}1.76 \\
1.61 \\
.64 \\
.29 \\
.30\end{array}$ & $\begin{array}{l}.111 \\
: 157 \\
: 280 \\
: 336 \\
.267\end{array}$ & $\begin{array}{l}.018 \\
.022 \\
.062 \\
.021 \\
.021\end{array}$ & $\begin{array}{l}2,00 \\
9,00 \\
135 \\
, 25 \\
118\end{array}$ \\
\hline $\begin{array}{l}17 \\
17 \\
17 \\
17 \\
17\end{array}$ & $\begin{array}{l}150 \\
200 \\
250 \\
304 \\
350\end{array}$ & $\begin{array}{l}11,001 \mathrm{AL}) \\
11,001 \mathrm{AL} \\
11,001 \mathrm{AL} \\
111000 \mathrm{AL} \\
11,00(\mathrm{AL})\end{array}$ & $\begin{array}{l}.194 \\
: 176 \\
: 248 \\
: 337 \\
: 395\end{array}$ & $\begin{array}{l}.013 \\
.035 \\
.035 \\
.070 \\
.085\end{array}$ & $\begin{array}{l}51,58 \\
29,90 \\
17,58 \\
11,22 \\
8,11\end{array}$ & $\begin{array}{l}.120 \\
1171 \\
1279 \\
.455 \\
.492\end{array}$ & $\begin{array}{l}.012 \\
1021 \\
1040 \\
.069 \\
.004\end{array}$ & $\begin{array}{r}14,50 \\
7,77 \\
3,86 \\
1,92 \\
1,63\end{array}$ & $\begin{array}{l}1103 \\
1126 \\
320 \\
1611 \\
611\end{array}$ & $\begin{array}{l}.010 \\
.012 \\
.089 \\
.055 \\
.061\end{array}$ & $\begin{array}{r}4.62 \\
3.04 \\
.97 \\
.43 \\
.34\end{array}$ & $\begin{array}{l}.112 \\
: 116 \\
: 247 \\
: 380 \\
.363\end{array}$ & $\begin{array}{l}.010 \\
.017 \\
.057 \\
.030 \\
.041\end{array}$ & $\begin{array}{l}1,57 \\
: 92 \\
: 86 \\
: 22 \\
19\end{array}$ \\
\hline $\begin{array}{l}17 \\
17 \\
17 \\
17 \\
17\end{array}$ & $\begin{array}{l}150 \\
200 \\
250 \\
300 \\
350\end{array}$ & $\begin{array}{l}6,00(C)) \\
6,00104) \\
6,001(0) \\
6,00(C) \\
6,00(C)\end{array}$ & $\begin{array}{l}.146 \\
: 201 \\
370 \\
387 \\
.413\end{array}$ & $\begin{array}{l}.020 \\
.018 \\
0.043 \\
.062 \\
.103\end{array}$ & $\begin{array}{r}35.55 \\
18.12 \\
8.19 \\
6.14 \\
4.78\end{array}$ & $\begin{array}{l}.101 \\
.220 \\
.394 \\
.412 \\
.566\end{array}$ & $\begin{array}{l}.015 \\
.020 \\
.053 \\
.055 \\
.049\end{array}$ & $\begin{array}{r}14,95 \\
5,05 \\
1,80 \\
1,29 \\
, 71\end{array}$ & $\begin{array}{l}.118 \\
.181 \\
360 \\
: 824 \\
.038\end{array}$ & $\begin{array}{l}.014 \\
.010 \\
.103 \\
.143 \\
.034\end{array}$ & $\begin{array}{r}4.90 \\
2.20 \\
.73 \\
.34 \\
.25\end{array}$ & $\begin{array}{l}.168 \\
.195 \\
1306 \\
.369 \\
.427\end{array}$ & $\begin{array}{l}.017 \\
.017 \\
.055 \\
.085 \\
.024\end{array}$ & $\begin{array}{l}1.52 \\
: 37 \\
: 37 \\
: 17\end{array}$ \\
\hline $\begin{array}{l}17 \\
17 \\
17 \\
17 \\
17 \\
17\end{array}$ & $\begin{array}{l}150 \\
200 \\
219 \\
250 \\
300 \\
350\end{array}$ & $\begin{array}{l}3,076 w \\
3.076 w \\
3,0766 \\
3,076 w \\
3,076 w) \\
3,076 w)\end{array}$ & $\begin{array}{l}0.004 \\
.186 \\
: 245 \\
.324 \\
.330 \\
.449\end{array}$ & $\begin{array}{r}-0,000 \\
.020 \\
.029 \\
.025 \\
.035 \\
.037\end{array}$ & $\begin{array}{l}0.00 \\
7.03 \\
3.94 \\
3.43 \\
2.18 \\
1.98\end{array}$ & $\begin{array}{l}.165 \\
.165 \\
.206 \\
.323 \\
.423 \\
.435\end{array}$ & $\begin{array}{l}.012 \\
.012 \\
0.023 \\
.023 \\
.022 \\
.027\end{array}$ & $\begin{array}{l}3,26 \\
2,10 \\
1,08 \\
: 99 \\
: 30\end{array}$ & $\begin{array}{l}1129 \\
1162 \\
1202 \\
1363 \\
1430 \\
1.05\end{array}$ & $\begin{array}{l}.020 \\
.012 \\
.025 \\
.062 \\
.035 \\
.026\end{array}$ & $\begin{array}{l}1.36 \\
.54 \\
.47 \\
.18 \\
.15 \\
.11\end{array}$ & $\begin{array}{l}.133 \\
.165 \\
1193 \\
.243 \\
.273 \\
.303\end{array}$ & $\begin{array}{l}.000 \\
.020 \\
.015 \\
1030 \\
.026 \\
.015\end{array}$ & $\begin{array}{l}98 \\
228 \\
20 \\
213 \\
100 \\
106\end{array}$ \\
\hline $\begin{array}{l}12 \\
12\end{array}$ & $\begin{array}{l}200 \\
350\end{array}$ & $\begin{array}{l}.25(c u) \\
.25(c u)\end{array}$ & $\begin{array}{l}.015 \\
.036\end{array}$ & .001 & $\begin{array}{l}8.28 \\
2.73\end{array}$ & .020 & $\begin{array}{l}.002 \\
.008\end{array}$ & $\begin{array}{l}1.79 \\
.86\end{array}$ & $\begin{array}{l}.014 \\
.027\end{array}$ & .001 & $\begin{array}{r}1.23 \\
.37\end{array}$ & $\begin{array}{r}3,258 \\
, 011\end{array}$ & $\begin{array}{l}.293 \\
.002\end{array}$ & $: \begin{array}{l}64 \\
: 23\end{array}$ \\
\hline
\end{tabular}

TABLE III

Yield in pions/sr/(GeV/c/incident proton Error in pions/sr/( $\mathrm{GeV} / \mathrm{c}) /$ incident proton $\mathrm{E} / \mathrm{PI}=$ number of electrons per pion

$\mathrm{AL}=\mathrm{a} 1$ uminum, $\mathrm{Cu}=$ copper, $\mathrm{W}=$ tungsten

CES OF NEGATIVE PIONS

\begin{tabular}{l|l|c}
\hline Accelerators & $\begin{array}{l}\text { Maximum } \\
\text { Protons/sec. }\end{array}$ & $\begin{array}{l}\text { rads/min. in } \\
\text { loocm í field }\end{array}$ \\
\hline LAMPF & $6 \times 10^{15}$ & 35 \\
A.G.S. & $6 \times 10^{12}$ & 24 \\
Z.G.S. & $1.2 \times 10^{12}$ & 2 \\
Bevatron & $1.4 \times 10^{12}$ & 1
\end{tabular}

